DOI 10.31558/2519-2949.2019.3.7

УДК 312.01

ORCID ID: https://orcid.org/0000-0003-2889-3990

Перепелиця Н. О., Київський національний університет імені Тараса Шевченка

\title{
ПОБУДОВА СИЛЬНОЇ ДЕРЖАВИ В КОНЦЕПЦІЇ ФРЕНСІСА ФУКУЯМИ
}

За останні роки у багатьох, якщо не у більшості країн світу, як в науковому баченні , так $i$ масовій свідомості поступово укорінюється тверде розуміння необхідності створення сильної $i$ потужної держави, з чітко прачюючими інститутами, здатної забезпечити належні гарантії громадянських прав і свобод, створити умови для успіху реформ. Сьогодні людство дуже гостро відчуває необхідність формування наукової конщепиії сильної держави і ї̈ подальшої практичної реалізації. Побудова сильної держави - одна з найбільш важливих проблем світової спільноти.

Його книги оригінальні, автор не є послідовним прихильником якої-небудь однієї філософської чи соиіологічної школи. Він поєднує декілька течій для створення однієї-найкращзої. Статті є завжди актуальними, відповідають тематиці сучасних політичних, соціальних і навіть екологічних проблем. Погляд Фукуями на побудову сильної держави иікавий і науковиям, $і$ широкому загалу.

В иій статті проаналізовано еволючію поглядів Френсіса Фукуями на побудову і становлення сильної держави, що є реальною необхідністю не лише для краӥн, ще перебувають на стадії тотального реформування та розвитку, але й для розвинених краӥн світу.

Було встановлено погляд Ф. Фукуями на на розуміння феномену «сильна держава», окремі ідеї щодо необхідності посилення держави, охарактеризовано основні аспекти, які сприяють посиленню ролі та ресурсного потениіалу побудови сильної держави.

В статті висвітлено технологію побудови американської моделі сильної держсави з точки зору Френсіса Фукуями і доведено, щзо тут головним критерієм сильної держави виступає набір соиіально-політичних функиій та иілей, які вона реалізує, а тому сильна держава розглядається крізь призму ї̈ слабкості не лише в державно-інституціональному аспекті, а і як інструмент тиску на суспільне життя.

В статті використовувались структурно-функиіональний (при аналізі особливостей поглядів Фукуями на розуміння сильної держави), порівняльний (при аналізі еволючї поглядів Фукуями на сильну державу), системний методи аналізу.

Ключові слова: держава, сильна держава, побудова сильної держави, Френсіс Фукуяма, децентралізація, сила.

Метою цієї статті є дослідження окремих аспектів побудови сучасної сильної держави на прикладі основних постулатів вчення американського філософа Френсіса Фукуями. Досягнення мети зумовлює необхідність вирішення відповідних завдань, а саме: розробити чіткі критерії та параметри змісту сильної держави, висвітлити технологію побудови американської моделі сильної держави з точки зору Френсіса Фукуями, проаналізовано еволюцію поглядів Френсіса Фукуями на побудову і становлення сильної держави, охарактеризувати основні аспекти, які сприяють посиленню ролі та потенціалу побудови сильної держави.

Аналіз останніх досліджень i публікацій, у яких започатковано розв'язання даної проблеми. Окремі аспекти проблеми побудови сильної держави були предметом окремого аналізу в працях учених майже кожного історичного періоду з часів виникнення полісів до утвердження постмодерної держави, серед яких Платон, Аристотель, Н.Макіавеллі, Д.Локк, Т.Гоббс, Ж-Ж.Руссо, І.Кант, Г.Гегель, К.Поппер, Е.Тоффлер, М.Крозіер, С. Хантінгтон, К. Фрідріх, З. Бжезинський, Леслі А. Пал, , Ф.Фукуяма та ін. За останній час з'явилася низка публікацій, що безпосередньо присвячені феномену сильної держави, авторами яких $є$ українські науковці О.Кіндратець, М.Шульга, М.Михальченко, В.М.Князєв, І.С.Кравченко, В.Г.Кремень, І.Ф.Надольний, О.І.Білорус, М.І.Михальченко, М.Мілова та інші. Переважна більшість із них під сильною державою розуміла «ефективну, повноцінну, авторитетну та впевнену в собі державу, яка чітко виконує всі свої функції і успішно реалізує своє соціальне призначення». 
Актуальність цієї теми засвідчують невщухаючі дискусії політиків, вчених на шпальтах періодичної літератури та засобах масової інформації. Першочерговим завданням для вітчизняної політичної науки $є$ активізація наукових пошуків в цьому напрямку та вироблення конкретних рекомендацій щодо впровадження ідеї сильної держави у державному будівництві.

Вступ. У своїй праці «Сильна держава. Управління та світовий порядок у ХХІ столітті» відомий американський філософ, соціолог та футуролог Френсіс Фукуяма доводить, що побудова сильної держави - одна із найбільш важливих проблем світового співтовариства, адже слабкість та руйнування держав слугує джерелом найбільш серйозних світових проблем: від бідності до СНІДу, наркотиків та тероризму $[5,5]$.

Більше тридцяти років ведучою тенденцією у світовій політиці було послаблення державності: зменшилась доля державного сектору та відбулося

навернення до ринку. При цьому ріст світової економіки призвів до руйнування автономії суверенних національних держав за рахунок збільшення швидкості обміну інформацією, мобільності капіталу $[5,197]$.

У Європі сучасна держава, яка має велику армію, сильні податкові органи, централізовану бюрократію, яка здійснює верховні повноваження на великій території, найбільше відповідає вимогам часу, хоча існує протягом 4-5 сторіч з часу утворення французької, іспанської та шведської монархій $[5,12]$.

Нові умови та проблеми сучасного існування цивілізації здійснили визначаючий вплив на функції сучасної держави. Розглядаючи розвиток та зміну функцій ми бачимо, як розвивалась та змінювалась державна організація суспільства в довготривалому історичному процесі. Функції держави не $\epsilon$ фундаментальними, застиглими та незмінними. В залежност і від конкретноісторичних умов вони можуть набувати самостійного значення, зникати через відсутність необхідності регулювання данного виду суспільних відносин, становитись глобальними для усього світу. У сучасної держави перелік функцій змінюється під впливом внутрішніх і зовнішніх умов. Так, епідемія СНІДу, що може призвести у майбутньому до грандіозних людських втрат, визначила виокремлення такого напряму удержавній діяльності як боротьба зі СНІДом. Відповідно 3'являється і такий новий напрям як боротьба з тероризмом.

На думку Френсіса Фукуями, у фокусі побудови сильної держави мова має йти саме про розширення ії функцій з метою вирішення різноманітних суспільних проблем $[5,6]$.

Дослідник виділяє у сучасної держави наступні категорії функцій:

- мінімальні (забезпечення явної суспільної користі; захист, закон та порядок; макроекономічне регулювання; суспільна охорона здоров'я, підвищення соціальної захищеності);

- проміжні функції (освіта; оточуюче середовище; регулювання монопол ій; соціальне страхування);

- активні функції (індустріальна політика; перерозподіл капіталу) [5, 25].

У формуванні державної політики вплив державних інститутів має посилюватися від мінімальних функцій через проміжні функції до активних функцій . Лише така державна політика буде ефективною . Вплив державних інститутів на суспільство має бути обмеженим (тобто , мається на увазі обмеження вищеназваних функцій).

Разом $з$ тим, сильна держава - це держава, яка здатна ефективно втілювати в життя власні політичні стратегії , дотримуючись певного політичного курсу та діючи строго в рамках законів.

Цікавою, на мою думку, видається еволюція поглядів відомого американського філософа i політолога Френсіса Фукуямы з вказаної вище проблеми. Чверть століття тому він проголосив у своїй значній роботі "Кінець історії"? відхід з історичної сцени великих держав, остаточну перемогу лібералізму і ринкової капіталістичної економіки у всьому світі i, як наслідок цього, настання епохи "постісторії" [4]. В цій роботі він характеризував "сильну державу" як тимчасову перешкоду на шляху до демократичного суспільства.

Але з наростанням політичних і ідеологічних проблем, символом яких стала терористична атака 11 вересня 2001 року, Ф. Фукуяма досить радикально переглянув свою позицію і став прибічником доктрини сильної держави. Свою книгу, опубліковану в 2004 році, Фукуяма так і назвав "Сильна держава: Управління і світовий порядок в XXI столітті". Книга відразу розпочинається із заяви наступної тези : "Побудова сильної держави полягає в створенні нових урядових установ і зміцненні існуючих. У цій книзі я показую, що побудова сильної держави одна 3 найбільш важливих проблем світової спільноти, оскільки слабкість і руйнування держав служить джерелом багатьох найбільш серйозних світових проблем".. Завершується книга також 
не менш симптоматичним затвердженням Ф. Фукуямы : "тільки держави і одні держави здатні об’єднати і доцільно розмістити сили забезпечення порядку. Ці сили потрібні, щоб забезпечити правління закону всередині країни і зберегти міжнародний порядок. Тi, хто виступає за "сутінки державності" - чи являються вони поборниками вільного ринку або віддані ідеї багатосторонніх переговорів,- повинні пояснити, що саме замінить силу суверенних національних держав у сучасному світі. Насправді цю прірву заповнили різношерсті збори міжнародних організацій, злочинних синдикатів, терористських груп і так далі, які можуть мати певною мірою владу i легітимність, але рідко можуть володіти і тим і іншим відразу. За відсутністю ясної відповіді нам залишається тільки повернутися до суверенної національної держави i знову спробувати зрозуміти, як зробити іï сильною і успішною." [5, с. 199].

Для Фукуямы ліберальні ідеології, що пропагують мінімізацію і обмеження державних функцій, не відповідають сучасним реаліям. Ідея лібералів про те, що приватні ринки і інститути громадянського суспільства повинні перекласти на себе деякі державні функції і це нібито приведе до ефективнішого функціонування усієї політичної системи, на думку Фукуямы, $є$ порочною. Френсіс Фукуяма стверджує, що слабкі, неосвічені, уявні уряди можуть бути джерелом досить серйозних проблем, особливо це стосується країн світу, що розвиваються $[5$, с. 6$]$.

Якщо Фукуяма у кінці 80-х - початку 90-х років минулого століття безапеляційно вважав, що у ліберальної ідеології немає більше реальних політичних альтернатив, що ліберальні цінності носять універсальний характер, то на початку XXI століття у нього із цього приводу з'явилися сумніви. Він навіть певною мірою солидаризовался з думкою Сэмюэля Хантингтона про те, що ліберальні цінності- це унікальний плід, що народився завдяки специфічним умовам розвитку Західної Європи.

3 одного боку, базові цінності ліберальної ідеології самі по собі мають особливу привабливість в глобальному масштабі, але з іншого боку, спроби експорту цих цінностей в інші національнокультурні регіони (особливо у відсталі країни, що розвиваються), як показала історична практика, часто терпіли невдачу. Аналіз результатів реформ в різних країнах, проведених по західних лекалах, наводить Фукуяму на думку про нездатність західних урядів стимулювати багатостороннє процвітання країн, що розвиваються.

Виникає законне питання: що ж заважає західним консультантам і творцям ліберальних реформ в інших країнах ефективно адаптувати до місцевих умов ці цінності. Фукуяма вважає, що реформатори робили головну ставку на послаблення впливу держави на різні сфери економіки, не замислюючись про створення єдиної концепції, в якій проблеми реорганізації державних і громадських установ взаємодіяли би з питаннями економічного розвитку. У результаті очікування від позитивної дії ліберально-економічних реформ не виправдалися. Крім того, відсутність необхідних державних i цивільних інститутів увергла економіку в деградацію, привела до плачевного стану, ще гіршого, ніж до початку реформ.

Ф.Фукуяма вважає, що після Холодної війни диктат політиків змінився інтелектуальним диктатом ліберально налагоджених економістів, що ратували за зменшення впливу державної влади. Але, відмічає Фукуяма, буквально в останнє десятиліття багато економісти сформулювали висновок, що досить велика частина найбільш суттєвих змінних, які впливають на розвиток, зовсім не економічні, а торкаються формальної сторони стосунків і політики. Інакше кажучи, абсолютно не враховувалися аспекти державності, досліджувати які було необхідно, тобто створення сильної держави з позицій розвитку, і які ігнорувалися, оскільки увага концентрувалась тільки на сфері впливу держави $[5$, с. 46$]$.

У 80-х роках XX століття американські політологи розробляли ідею децентралізації політичної влади і делегування іiі на рівень керівництва штатів і органів місцевого самоврядування. Вважалося, що децентралізація буде прив'язана до місцевих джерел інформації, а, отже, оперативно і швидко реагуватиме на зміни в місцевих умовах. Політичні рішення на місцевому рівні приймає велика кількість учасників, що в свою чергу веде до конкуренції ідей і пошуку оптимальних шляхів впровадження соціальних інновацій. Не потрібно забувати, що ідеологія політичного федералізму припускає ідею доступності влади народу, звітності і транспорентности діяльності уряду, тобто легітимності влади і підвищенню якості демократичних свобод.

Ф.Фукуяма, аналізуючи технологію побудови американської моделі сильної держави, виходив 3 ідеї «роззосередження влади на місцях, іiі децентралізації, що тим самим послабляє силу іiі адміністративного впливу, але саме це і робить державу сильною» [5, с. 218]. Інакше кажучи, тут головним критерієм сильної держави виступає набір соціально-політичних функцій та цілей, які 
вона реалізує, а тому сильна держава розглядається крізь призму ії слабкості не лише в державноінституціональному аспекті, а і як інструмент тиску на суспільне життя.

Аналогічні установки, на думку Фукуямы, привели деяких фахівців до гіпотези, що в соціумі наявне постійне прагнення до децентралізації i горизонтального делегування повноважень в організаційній системі. Але як вважає американський політолог, усе це вкрай сумнівно, оскільки "у децентрализованных організацій $є$ свої недоліки, проблема усунення яких не має технічного рішення. Децентрализованность організації часто породжує високі внутрішні організаційні витрати, і такі організації можуть виявитися повільнішими і менш рішучішими, чим централізовані. Так, хоча військові організації зазвичай наділяють значними повноваженнями по командуванню на місцях самі нижчі ешелони, вони проте зберігають високу міру централізованого контролю над рішеннями на стратегічному або операційному рівні" [5, с. 122-123].

На думку Фукуямы, принципи державного i національного суверенітету, закріплені у Вестфальской системі, в Статуті $\mathrm{OOH}$, в угодах Хельсінкі нині практично не дотримуються. Але процеси, що протікають усередині одних державах, нерідко чинять значну дію на інші країни, аж до порушення їх суверенітету. I Фукуяма резонно задає низку запитань : хто має право або законну причину порушувати суверенітет будь-якої іншої країни, i, що не менш важливо, в ім'я яких цілей? чи не залежить сама міжнародна легітимність від наявності суверенних держав, а також і від їх сили? якщо залежить, то тоді, чи не суперечить цьому принципу порушення суверенітету інших держав? [5, с. 157].

Проблема блокового протистояння після завершення Холодної війни змінилася новою міжнародною загрозою - наявністю "слабких" держав або за виразом Фукуямы, держав-"невдах". Під терміном "слабкий" Фукуяма розуміє не розміри або масштаб держави, а певну систему управління, що гальмує нормальний розвиток економіки, корінь цього "гріха" американський політолог бачить в нелегітимності усієї політичної надбудови.

Головними характеристиками "слабких" держав або держав-"невдах", на думку Фукуямы, являються: порушення прав людини, корупція, нерозвиненість інститутів громадянського суспільства, некомпетентність керівників, постійні соціальні потрясіння. Усе це веде до озброєних конфліктів з сусідніми країнами, а також $є$ головним джерелом масової імміграції. Слабкі держави $\epsilon$ джерелом не лише матеріальної, а й духовно-ідеологічної підтримки міжнародного тероризму.

До "слабких" держав Фукуяма відносить Сомалі, Гаїті, Боснію, Косово, Руанду, Ліберію, Сьєрра-Леоне, Конго, Афганістан і Східний Тимор. 3 різною мірою ефективності в рішення конфліктів усередині цих країн нерідко були залучені міжнародні коаліції.

Фукуяма у своій роботі особливе місце відводить ролі Сполучених Штатів в рішенні подальшої долі "слабких" держав.

Фукуяма стверджує, що традиційні форми підтримки безпеки нині мало дієві, їх вимагається замінити ефективнішими і навіть превентивними. Для вирішення проблем усередині "слабких" держав, для блокування подальшої небезпеки з їх боку нерідко потрібно зміну правлячих там режимів. Таким чином, згідно з Фукуяме, проблема "слабких" держав, яка розглядалася раніше як соціогуманітарна проблема або проблема прав людини, на сьогодні безпосередньо відбивається на безпеці інших країн. На думку Фукуямы, логіка зовнішньої політики США після 11 вересня 2001 р. "підводить iї до такої ситуації, при якій вона або бере на себе відповідальність за керівництво слаборозвиненими державами, або передає цю місію до рук міжнародного співтовариства. Заперечуючи свої імперські амбіції, адміністрація Буша проте сформулювала (у мові президента у Вестпойнте в червні 2002 року і в Документі по стратегії національної безпеки 2002 роки) доктрину профілактичної або, точніше, превентивної війни, яка фактично ставить Сполучені Штати в положення влади над потенційно ворожим населенням країн, загрожуючих Америці тероризмом". [5, с. 161].

Відповідальність за керівництво слаборозвиненими державами, яку поклали на себе Сполучені Штати, постійно призводить до порушення суверенітету інших країн і підриває світовий лад. На думку Фукуямы, це обумовлено тим, що слабкі держави породжують цілий комплекс проблем, як для себе, так і для інших держав, що свою чергу підвищує вірогідність того, що яка-небудь держава може втрутитися у внутрішні справи слабких країн без урахування їх інтересів.

Деякі фахівці, що критикували доктрину адміністрації Буша про превентивну війну i не підтримали ідею введення військ в Ірак, розглядали цю теорію як ознаку радикального відходу від колишньої політики стримування, оскільки вона припускала часте порушення суверенітету інших держав. Фукуяма вважає, що подібна практика порушення суверенітету склалася в 90-і роки 
XX століття, і про неї можна судити по наслідках від так званої гуманітарної інтервенції в таких країнах як Сомалі, Гаїті, Камбоджа, колишня Югославія.

В ході дискусій з питань гуманітарної інтервенції відзначалося, що Вестфальська система в нових умовах вже не $\epsilon$ ефективним механізмом регулювання світової спільноти. На думку Фукуямы, у Вестфальській системі відсутній один, але важливий елемент - розуміння проблеми легітимності.

Фахівці відмічали, що завершення Холодної війни сприяло формуванню консенсусу з основних принципів політичної легітимності i прав людини в глобальному масштабі. Нині визнання суверенітету і легітимності будь-якої держави або уряду не здійснюється автоматично.

Складність полягає в тому, що навіть якщо світовій спільноті і вдавалося якимсь чином врегулювати конфлікти усередині і між "слабкими" державами, то спроби побудувати там "сильну" державу, реконструювати або створити наново самостійні соціально-політичні інститути, ефективно реорганізувати економічну систему, як правило, провалювалися або досягнуті результати були дуже скромними. Як пише Фукуяма: "Ні Сполучені Штати, ні міжнародне співтовариство не досягли особливих успіхів у справі побудови самостійних держав ні в одній з країн, де вони мали намір це зробити. Проте спроби побудови сильних держав зіграли важливу роль в стабілізації обстановки в цих країнах і в підготовці грунту для можливих переговорів. Мир - це неоціниме благо для народів воюючих країн, він виправдовує усі міжнародні зусилля в цьому напрямі. Але міжнародне співтовариство підкреслює важливість відновлення управлінських інститутів, створення інфраструктури".

Таким чином, еволюція поглядів Френсіса Фукуями йшла від лібералізму у бік доктрини сильної держави. Причому в уявленнях Фукуями сильна держава це не аналог тоталітарної або авторитарної держави. У його концепції "сила" держави розглядається на двох рівнях:

1) внутрішньому, здатному забезпечити громадянам соціальну безпеку, політичну стабільність, економічне процвітання;

2) зовнішньому, такому, що забезпечує конкурентоспроможність країни, ефективність іiі протидії численним викликам глобалізації.

\section{Висновки}

Отже, аналіз концептуальних положень щодо побудови сильної держави, викладених Ф.Фукуямою, дозволяє зробити наступні висновки. По-перше, проблема зміцнення держави в наш час набуває не лише особливої актуальності, але й характеризується очевидною складністю, об'ємністю та багатовимірністю. Така ситуація створює потужні стимули для розвитку концепту „сильної держави” в межах оновленої політичної теорії, котра не просто більш конкретно та ретельно тлумачить дійсність, а грунтується на осмисленні й розв'язанні сучасних проблем, враховуючи певний екстремальний стан сучасної цивілізації. Ігнорування останньої обставини загрожує тим, що суспільно-політична теорія відставатиме у тлумаченні швидкоплинних подій, буде нездатною розуміти та враховувати специфіку суспільно-політичного буття, породжуючи тим самим практику імпульсивного, неадекватного реагування на зовнішні та внутрішні загрози на рівні людства, окремих держав та націй. По-друге, очевидно, що у реальній політичній практиці модель ніколи не спрацьовує з таким ступенем ефективності, на який сподіваються іiі творці. Втім, за сучасних умов надзвичайного ускладнення i неоднозначності геополітичної ситуації, розпорошеності політичних сил всередині, коли важко визначити правильну стратегію розвитку, побудова сильної, дієздатної держави - це єдиний позитивний сценарій, Відмова від нього призведе до вкрай негативних наслідків для майбутнього країни, що межують 3 національним крахом. Іншими словами, мова йде про вибір: або країна стане сильною, або вона просто зникне зі світової арени як значимий геополітичний, національно-державний та соціально-економічний суб' єкт.

Отже, базовим підгрунтям сильних держав є чітке підпорядкування законам , що врешті сприятиме політичній стабільності. Відповідно, поняття сильної держави в контексті теорії Ф. Фукуями передбачає, з одного боку , обмеження сфери впливу держави , скорочення іiї функцій , а з іншого - наявність сильних та ефективних державних інститутів, що чітко дотримуються законів. У його концепції "сила" держави розглядається на двох рівнях: 1) внутрішньому, здатному забезпечити громадянам соціальну безпеку, політичну стабільність, економічне процвітання; 2) зовнішній, такий, що забезпечує конкурентоспроможність країни, ефективність його протидії численним викликам глобалізації. Проте слід підкреслити, що чітко сформульованої концепції „сильної держави” у політичній думці досі не створено. Кожне політичне вчення, по суті, прагне до створення ідеально-теоретичної моделі сильної держави, віддаючи перевагу різним аспектам. 


\section{Бібліографічний список:}

1. Дубовик Н.А. Феномен сильної держави: теоретичні аспекти практичних проблем / Н.А. Дубовик, В.Г. Пугач // Вісник Національного технічного університету України "Київський політехнічний інститут" : збірник наукових праць / Національний технічний університет України "Київський політехнічний інститут". Київ, 2010. - С. 7-13. - (Політологія. Соціологія. Право ; № 3 (7)).

2. Петров М. П. Сильное государство и активная личность как потребность времени / М. П. Петров // Правовая политика и правовая жизнь. - 2010.- №3. -С. 190-213.

3. Топорнин Б. Н. Сильное государство - объективная потребность времени / Б. Н. Топорнин // Вопросы философии. - 2011. - № 7. - С. 20-37.

4. Фукуяма Ф. Конец истории и последний человек / Френсис Фукуяма. - М.: "АСТ", 2004. - 592 с.

5. Фукуяма Ф. Сильное государство: Управление и мировой порядок в XXI веке : [пер. с англ.] / Фрэнсис Фукуяма.- М. :АСТ :АСТ Москва: хранитель, 2006. - 220 с.

\section{References:}

1. Dubovyk N.A. (2010). The phenomenon of a strong state: theoretical aspects of practical problems. Visnyk Natsionalnoho tekhnichnoho universytetu Ukrainy 'Kyivskyi politekhnichnyi instytut' Politolohiia. Sotsiolohiia. Pravo, 3 (7), 7-13 [in Ukrainian].

2. Petrov M. P. (2010). A strong state and an active personality as a need for time. Pravovaya politika i pravovaya zhizn, 3, 190-213 [in Russian].

3. Topornin B. N. (2011). A strong state is an objective need of time. Voprosy filosofii, 7, 20-37 [in Russian].

4. Fukuyama F. (2004). The End of History and the Last Man. M.: "AST", 592 [in Russian].

5. Fukuyama F. (2006). State-Building: Governance and World Order in the 21st Century. Moskva AST, 220 [in Russian].

\section{Perepelytsia N. O., Building a strong state in the concept of Francis Fukuyama}

In recent years, in many countries, both in science and in the mass consciousness, there has been a steady understanding of the need to create a strong and powerful state, with well-functioning institutions capable of providing the proper guarantees of civil rights and freedoms, the success of the reforms. Today, humanity is very keen to formulate a scientific concept of a strong state and its further practical implementation. Building a strong state is one of the most important problems of the world community.

His books are original, the author is not a consistent supporter of any one philosophical or sociological school. It combines several streams to create one - the best. The articles are always relevant, relevant to the topics of contemporary political, social and even environmental issues. Fukuyama's view on building a strong state is of interest to both scholars and the general public.

This article analyzes the evolution of Francis Fukuyama's views on building and becoming a strong state, which is a real necessity not only for countries undergoing total reform and development, but also for the developed world.

F. Fukuyama's view on understanding the phenomenon of "strong state", some ideas on the need to strengthen the state were identified, the main aspects contributing to the strengthening of the role and resource potential of building a strong state were outlined.

The article deals with the technology of constructing the American model of a strong state from the point of view of Francis Fukuyama and proves that the main criterion of a strong state is a set of sociopolitical functions and goals that it realizes, and therefore a strong state is viewed through the prism of its weakness not only institutional aspect, but also as a tool of pressure on public life.

The article used structural-functional (in the analysis of features of Fukuyama views on the understanding of a strong state), comparative (in the analysis of the evolution of Fukuyama views on a strong state), systematic methods of analysis.

Key words: state, strong state, building a strong state, Francis Fukuyama, decentralization, power. 